
FIT(1)PATOLOGI
Volume 16, Nomor 1, Januari 2020
Halaman $37-48$
ISSN: 0215-7950
DOI: $10.14692 /$ jfi.16.1.37-48

\title{
Bakteri Agens Hayati Potensial terhadap Patogen Penting pada Padi
}

\section{The Potential Biological Agent Bacteria Against for Controling Important Pathogens on Rice}

\author{
Ratna Sari Dewi $^{1}$, Giyanto ${ }^{1 *}$, Meity Suradji Sinaga ${ }^{1}$ Dadang $^{1}$, Bambang Nuryanto ${ }^{2}$ \\ ${ }^{1}$ Institut Pertanian Bogor, Bogor 16680 \\ ${ }^{2}$ Balai Besar Penelitian Tanaman Padi, Subang 41256
}

\begin{abstract}
ABSTRAK
Saat ini teknologi pengendalian hayati penyakit utama padi terus berkembang. Dalam pengembangan teknologi pengendalian hayati, mekanisme penghambatan patogen dalam perkembangan penyakit pada suatu populasi tumbuhan dalam area tertentu menjadi hal yang penting. Penelitian bertujuan mendapatkan bakteri agens hayati potensial dalam pengendalian penyakit penting padi di antaranya yang disebabkan Pyricularia oryzae, Xanthomnas oryzae pv. oryzae, Rhizoctonia solani, Burkholderia glumae, dan Drechlera oryzae, berdasarkan mekanisme antagonisme, kemampuan menginduksi ketahanan dan mendukung kebugaran tanaman, serta kompatibilitas antaragens hayati. Ralstonia pickettii TT47, Pseudomonas fluorescens P12, Chromobacterium sp. T51118, Bacillus subtilis 451 dan 154, serta Streptomyces sp. T51105 dibuktikan memiliki mekanisme antibiosis dengan menghasilkan metabolit sekunder dan senyawa volatil. Berdasarkan uji produksi enzim kitinolitik Chromobacterium sp. dan Streptomyces sp. memiliki mekanisme lisis. Aktivitas antibiotik R. pickettii dan P. fluorescens tergolong kuat terhadap $P$. oryzae dengan penekanan secara berurutan sebesar $79.68 \%$ dan $77.59 \%$ pada uji biakan ganda. Penekanan pertumbuhan miselium $P$. oryzae dan $R$. solani pada uji volatil mencapai $100 \%$ oleh Chromobacterium sp. Semua agens hayati umumnya mampu menginduksi ketahanan dan mendukung kebugaran tanaman. Uji kompatibilitas menunjukan R. pickettii, P. fluorescens, dan Chromobacterium sp. bersifat kompatibel. Dari hasil penelitian diperoleh tiga bakteri agens hayati dengan kategori unggul, yaitu P. fluorescens P12, R. pickettii TT47, dan Chromobacterium sp. T51118. Ketiganya mampu menekan pertumbuhan patogen, menginduksi ketahanan dan mendukung kebugaran tanaman, memiliki patogen sasaran yang lebih beragam, serta bersifat kompatibel.
\end{abstract}

Kata kunci: antibiosis, induksi ketahanan, pelarutan fosfat, siderofor, volatile

\begin{abstract}
At present, biological control technology for the main diseases of rice continues to grow. In the development of biological control technology, inhibition mechanism of pathogens in the development of disease in a plant population in a certain area becomes important. The aim of this study was to obtain potential biological agent bacteria for controlling important rice diseases based on antagonistic mechanism, ability to induce plant resistance and support plant fitness, and their compatibility. The results showed that Ralstonia pickettii TT47, Pseudomonas fluorescens P12, Chromobacterium sp. T51118, Bacillus subtilis 451 and 154, and Streptomyces sp. T51105 have an antibiosis mechanism by producing secondary metabolites and volatile compounds. Additionaly, Chromobacterium sp. and

*Alamat penulis korespondensi: Departemen Proteksi Tanaman, Fakultas Pertanian, Institut Pertanian Bogor, J1 Kamper, Kampus IPB Dramaga, Bogor 16680.

Tel: 0251-8629364, Faks: 0251-8629362, surel: giyanto@apps.ipb.ac.id
\end{abstract}


Streptomyces sp. also have a lysis mechanism on the basis of the chitinolityc enzyme production test. The antibiotic activity of $R$. pickettii and P. fluorescens were strong to P. oryzae on dual culture test with the highest inhibition up to $79.68 \%$ and $77.59 \%$ respectively. Inhibition growth of $P$. oryzae and $R$. solani mycelium on volatile tests up to $100 \%$ by Chromobacterium sp. T51118. Generally, all of biological agents were able to induce plant resistance and support to plant fitness. Compatibility test obtained R. pickettii, P. fluorescens, and Chromobacterium sp. were compatible. Based on the results, three biocontrol agent bacteria, namely P. fluorescens P12, R. pickettii TT47, and Chromobacterium sp. T51118 were excellent. They were able to suppress the growth of pathogens, were able to induce plant resistance and support plant fitness, as well as they have more diverse target pathogens, and compatible.

Key words: antibiosis, plant resistant inducer, phosphorus solubilization, siderophore, volatile

\section{PENDAHULUAN}

Penyakitpada tanamanpadi sangatberagam, beberapa di antaranya digolongkan sebagai penyakit penting karena kehilangan hasil yang diakibatkannya cukup signifikan dalam memengaruhi upaya pemenuhan produksi beras nasioanal. Jenis penyakit penting tersebut ialah penyakit blas oleh Pyricularia oryzae, hawar daun bakteri oleh Xanthomonas oryzae pv. oryzae, hawar pelepah oleh Rhizoctonia solani, bercak cokelat oleh Drehclera oryzae, dan busuk bulir padi (bacterial grain rot) oleh Burkholderia glumae.

Pengendalian penyakit tanaman padi oleh petani masih didominasi penggunaan pestisida sintetik, sementara pengendalian hayati masih sangat rendah. Pengendalian hayati pada tanaman padi masih terbatas karena masih sedikit agens hayati potensial yang dapat dikembangkan sebagai teknologi pengendalian.

Keterbatasan jenis agens hayati menjadi tantangan tersendiri untuk dilakukannya studi dalam rangka mendapatkan agens hayati potensial sebagai kandidat dalam pengembangan pengendalian hayati. Ralstonia pickettii TT47, Chromobacterium sp. galur T51118, Pseudomonas fluorescens P12, Bacillus subtilis EB4 451, B. subtilis EA2 154, dan Streptomyces sp. galur T51105 merupakan bakteri yang dilaporkan bersifat antagonis terhadap beberapa patogen penting padi. Chromobacterium sp. galur T51118 dan Streptomyces sp. galur T51105 diketahui bersifatantagonisterhadap X.oryzaepv.oryzae, $R$. pickettii terhadap $R$. solani, $P$. fluorescens
P12 terhadap P. oryzae, sementara B. subtilis EB4 451 dan EA2 154 mampu menginduksi ketahanan tanaman dengan mengekspresikan gen PR 1 (Rustam 2012; Kurniawati 2016; Nurfadillah 2016; Parida 2016). Berdasarkan informasi tersebut, kajian lanjut terhadap potensi enam agens hayati ini masih diperlukan sebagai dasar seleksi agens hayati potensial. Penelitian bertujuan mendapatkan bakteri agens hayati potensial dalam pengendalian penyakit penting padi berdasarkan mekanisme antagonisme, kemampuan menginduksi ketahanan dan mendukung kebugaran tanaman, serta kompatibilitas antaragens hayati.

\section{BAHAN DAN METODE}

\section{Bakteri Agens Hayati dan Patogen Uji}

Agens hayati uji terdiri atas bakteri kelompok Gram negatif dan positif. Bakteri Gram negatif meliputi $R$. pickettii TT47, Chromobacterium sp. galur T51118, dan $P$. fluorescens P12, sedangkan bakteri Gram positif terdiri atas Streptomyces sp. galur T51105, Bacillus subtilis EA2 154 dan $B$. subtilis EB4 451.

Lima patogen uji yang digunakan ialah $X$. oryzae pv. oryzae, Burkholderia glumae KKe4, P. oryzae ras $137, R$. solani, dan Drechslera oryzae. Biakan B. glumae Kke4 dan D. oryzae berasal dari koleksi Laboratorium Bakteriologi Tumbuhan, Departemen Proteksi Tanaman, IPB, sedangkan P. oryzae, $R$. solani, dan $X$. oryzae pv. oryzae berasal dari Laboratorium Proteksi Tanaman, Balai Besar Penelitian Tanaman Padi (BB Padi). 
Mekanisme Pengendalian Agens Hayati terhadap Patogen Padi

Sebanyak 6 agens hayati dan 5 patogen padi digunakan dalam penelitian ini. Pengujian terdiri atas uji antibiosis, produksi senyawa volatil, dan enzim kitinolitik. Setiap uji diulang tiga kali. Mekanisme antibiosis dilakukan melalui uji biakan ganda. Uji produksi senyawa volatil dan enzim kitinolitik dilakukan untuk mengonfirmasi adanya aktivitas dalam penekanan perkembangan patogen uji dan aktivitas senyawa antibiotik. Hal ini dilakukan karena uji biakan ganda tidak dapat memisahkan penekanan perkembangan patogen terjadi akibat aktivitas antibiotik, senyawa volatil, atau adanya kerja enzim kitinolitik.

Uji Biakan Ganda. Pengujian terhadap bakteri patogen menggunakan metode crossstreak (Velho-Pereira dan Kamat 2011) yang dimodifikasi, yaitu dengan menggoreskan agens hayati uji secara menyeluruh pada sepertiga bagian dari diameter cawan selebar $\pm 3 \mathrm{~cm}$. Selanjutnya cawan diinkubasi selama 3 hari. X. oryzae pv. oryzae atau B. glumae digoreskan secara tegak lurus terhadap goresan agens hayati dengan jarak $\pm 0.5 \mathrm{~cm}$ dari tepi goresan agens hayati. Goresan berbentuk garis tunggal dan dibuat sebanyak empat goresan dengan panjang goresan $\pm 3 \mathrm{~cm}$ dan lebar \pm 0.2 $\mathrm{cm}$. Modifikasi dari metode Velho-Pereire dan Kamat (2011), yaitu dari aspek cara dan posisi inokulasi agens hayati. Metode inokulasi ini dilakukan pada bagian tengah berupa goresan tunggal sepanjang $7 \mathrm{~cm}$ dan lebar $0.5 \mathrm{~cm}$. Pengujian terhadap cendawan dilakukan berdasarkan pada metode yang dideskripsikan Haggag dan Soud (2012).

Persentase penghambatan terhadap bakteri $(\mathrm{PPb})$ patogen dihitung dengan rumus:

$$
\mathrm{PPb}(\%)=\frac{\mathrm{AWG}}{\mathrm{TSA}} \times 100, \text { dengan }
$$

AWG, panjang daerah goresan yang tidak ditumbuhi bakteri; dan TSA, panjang total goresan (Velho-Pereira dan Kamat 2011), sementara penghambatan terhadap cendawan (PPc) dihitung dengan rumus:

$$
\operatorname{PPc}(\%)=\frac{(\mathrm{R} 1-\mathrm{R} 2)}{\mathrm{R} 1} \times 100, \text { dengan }
$$

$\mathrm{R} 1$, jari-jari koloni hifa yang tumbuh menjauhi agens hayati; R2, jari-jari koloni hifa yang tumbuh mendekati agens hayati (Skidmore dan Dockinson 1976).

Produksi Senyawa Volatil. Pengujian dilakukan berdasarkan pada metode Sivan et al. (1987) dan diulang sebanyak tiga kali. Pengamatan penekanan pertumbuhan cendawan dilakukan dengan mengukur diameter koloni pada hari ke-5 setelah inkubasi, kecuali untuk pengujian terhadap $R$. solani yang diamati pada hari ke-2 dikarenakan miselium $R$. solani pada perlakuan kontrol telah menutupi semua permukaan medium pada cawan petri. Besarnya penghambatan dihitung dengan membandingkan diameter koloni pada perlakuan agens hayati dengan diameter koloni pada perlakuan kontrol. Pengamatan terhadap bakteri dilakukan tiga hari setelah inkubasi dengan cara menghitung hasil visualisasi pertumbuhan bakteri menggunakan software ImageJ. Besarnya penghambatan dihitung dengan membandingkan antara intensitas ketebalan pertumbuhan bakteri hasil analisis Image $J$ pada perlakuan agens hayati dengan perlakuan kontrol.

Kekuatan aktivitas penghambatan pada uji biakan ganda dan senyawa volatil ditentukan berdasarkan kategori Kartika et al. (2003) yang dimodifikasi, yaitu aktivitas kuat jika penghambatan pertumbuhan $\geq 50 \%$, aktivitas sedang jika $30 \% \leq$ penghambatan $<50 \%$, dan lemah jika penghambatan $<30 \%$.

Produksi Enzim Kitinolitik. Pengujian dilakukan berdasarkan metode Singh et al. (1999) pada medium agar koloidal kitin. Pengamatan dilakukan pada hari ke-7 setelah inokulasi dengan mengukur diameter zona bening yang terbentuk. Indeks kitinolitik (IK) dihitung dengan membandingkan diameter zona bening dengan diameter koloni agens hayati (Faramarzi et al. 2009).

\section{Uji Potensi Penginduksi Ketahanan Agens Hayati}

Induksi Agens Hayati. Induksi agens hayati dilakukan melalui perendaman benih padi varietas Ciherang dalam suspensi agens hayati (kerapatan $10^{9} \mathrm{cfu} \mathrm{mL}^{-1}$ ) selama $12 \mathrm{jam}$, 
selanjutnya benih ditanam pada medium tanam yang telah dicampur dengan suspensi agens hayati (kerapatan $10^{7} \mathrm{cfug}^{-1}$ ). Perlakuan diulang tiga kali. Analisis total fenol, aktivitas kitinase, peroksidase, dan phenylalanine ammonia lyase (PAL) dilakukan saat tanaman berumur 14 hari setelah semai (Murthy et al. 2014).

Analisis Total Fenol. Analisis total fenol dilakukan berdasarkan metode Murthy et al. (2014). Perubahan warna biru diukur absorbansinya pada $\lambda=725 \mathrm{~nm}$ dengan katekol sebagai standar. Jumlah fenolat dinyatakan sebagai mg katekol $\mathrm{mg}^{-1}$ protein.

Aktivitas Kitinase. Ekstraksi protein dilakukan berdasarkan metode Sukma et al. (2012). Aktivitas kitinase ditentukan berdasarkan kemampuannya untuk mendegradasi substrat dimer pnitrophenil $N$-asetil $\beta$-D glucosaminide (pNP-NacGluc). Nilai absorbansi diukur pada $\lambda=405 \mathrm{~nm}$. Aktivitas kitinase dihitung sebagai banyaknya pNP NacGluc (mM) yang dibebaskan per jam per $\mathrm{mg}$ protein (mM pNP jam ${ }^{-1} \mathrm{mg}^{-1}$ protein).

Aktivitas Peroksidase. Ekstraksi protein berdasarkan metode Kar dan Mishra (1976), sementara analisis enzim berdasarkan metode yang dideskripsikan Sukma et al. (2012). Purpurogallin yang terbentuk diukur nilai absorbansinya pada $\lambda=420 \mathrm{~nm}$ setiap 30 detik dalam periode $0-150$ detik. Aktivitas peroksidase dihitung sebagai peningkatan nilai absorbansi per satuan waktu per bobot protein $\left(\Delta \mathrm{A}_{420}\right.$ menit $^{-1} \mathrm{mg}^{-1}$ protein $)$.

Aktivitas PAL. Aktivitas PAL ditentukan berdasarkan metode yang dideskripsikan oleh Ngadze et al. (2012). Konsentrasi asam transcinamic diukur pada $\lambda=290 \mathrm{~nm}$ dan aktivitas enzim dinyatakan sebagai $\mathrm{A}_{290} \mathrm{mg}$ cinnamic acid menit ${ }^{-1} \mathrm{mg}^{-1}$ protein.

Peningkatan total fenol, akivitas enzim kitinase, feoksidase, dan PAL tanaman sebagai respons adanya induksi agens hayati dinyatakan dalam persentase peningkatan terhadap kontrol.

\section{Karakterisasi Sifat Agens Hayati dalam Mendukung Kebugaran Tanaman}

Produksi Siderofor. Pengujian menggunakan metode paper disc diffusion pada medium agar-agar chrome azurol sulfonat (CAS) (Alexander dan Zuberer 1991). Pengamatan dilakukan dengan mengukur diameter zona oranye yang terbentuk pada dua hari setelah inokulasi (HSI). Indeks siderofor (IS) dihitung dengan membandingkan diameter zona oranye dengan diameter koloni agens hayati.

Produksi Fosfatase. Pengujian dilakukan dengan metode paper disc diffusion (Mishra et al. 2011) pada medium agar pikovskaya, selanjutnya diinkubasi pada suhu ruang selama empat hari. Zona bening yang terbentuk mengindikasikan adanya kemampuan pelarutan fosfat. Indeks kelarutan fosfat (IKP) dihitung dengan membandingkan diameter zona bening dengan diameter koloni (Karpagam dan Nagalakshmi 2014).

\section{Uji Kompatibilitas Agens Hayati Potensial}

Uji kompatibilitas dilakukan secara berpasangan antara dua jenis agens hayati. Pengujian dilakukan berdasarkan metode Mishra et al. (2011) pada medium agar nutrien. Kompatibilitas antaragens hayati ditentukan berdasarkan pada terbentuk atau tidaknya zona bening di sekitar kertas saring.

\section{HASIL}

\section{Mekanisme Pengendalian Enam Agens Hayati terhadap Patogen Penting Padi}

Enam agens hayati uji memiliki potensi menekan patogen melalui mekanisme antibiosis dan lisis, selain itu juga berpotensi sebagai penginduksi ketahanan dan pendukung kebugaran tanaman (Tabel 1). Uji biakan ganda dan uji senyawa volatil, serta uji produksi enzim kitinolitik, menunjukan bahwa penekanan terhadap patogen terjadi akibat adanya mekanisme antibiosis dengan menghasilkan metabolit sekunder dan senyawa volatil, serta pada uji produksi enzim kitinolitik, dua agens hayati, yaitu Chromobacterium sp. T51118 dan Streptomyces sp. T51105 menunjukkan adanya mekanisme lisis. Adanya mekanisme antibiosis dengan menghasilkan metabolit sekunder berupa senyawa antibiotik dan senyawa volatil dapat dilihat dari hasil uji 
Tabel 1 Mekanisme pengendalian enam agens hayati

\begin{tabular}{lcccc}
\hline \multirow{2}{*}{ Agens hayati } & \multicolumn{4}{c}{ Mekanisme pengendalian } \\
\cline { 2 - 5 } & Antibiosis & $\begin{array}{c}\text { Produksi enzim } \\
\text { kitinase }\end{array}$ & $\begin{array}{c}\text { Induksi } \\
\text { ketahanan }\end{array}$ & $\begin{array}{c}\text { Pendukung } \\
\text { kebugaran }\end{array}$ \\
\hline Ralstonia pickettii TT47 & + & - & + & + \\
Chromobacterium sp. T51118 & + & + & + & + \\
Pseudomonas fluorescens P12 & + & - & + & + \\
Streptomyces sp. T51105 & + & + & + & + \\
Bacillus subtilis EA2 154 & + & - & + & + \\
Bacillus subtilis EB4 451 & + & - & + & + \\
\hline
\end{tabular}

biakan ganda (Gambar 1), sementara adanya aktivitas senyawa volatil dalam menekan pertumbuhan patogen dibuktikan dari hasil uji senyawa volatil (Gambar 2).

Mekanisme lisis oleh Chromobacterium sp. T51118 dan Streptomyces sp. T51105 dalam menekan patogen dibuktikan dengan hasil uji produksi enzim kitinolitik menggunakan medium agar koloidal kitin. Kedua agens hayati ini mampu mendegradasi komponen kitin yang terkandung dalam medium yang ditunjukkan oleh terbentuknya zona bening di sekitar kedua agens hayati ini (Gambar 3).

Besarnya penekanan setiap agens hayati terhadap pertumbuhan 5 patogen uji akibat adanya mekanisme antibiosis dan indeks kitinolitik disajikan pada Tabel 2 . Penekanan pertumbuhan enam agens hayati cukup bervariasi. Hasil uji biakan ganda menunjukkan bahwa penekanan pertumbuhan oleh $R$. pickettii dan $P$. fluorescens tergolong kuat terhadap $P$. oryzae dengan penekanan secara berurutan sebesar $79.68 \%$ dan $77.59 \%$, sementara aktivitas senyawa volatil yang kuat diperlihatkan oleh Chromobacterium sp. terhadap $P$. oryzae dan $R$. solani dengan penekanan tertinggi hingga $100 \%$.

Chromobacterium sp. galur T51118 dan Streptomyces sp. galur T51105 diketahui mampu memproduksi enzim kitinolitik. Tingginya kemampuan kedua bakteri ini dalam mendegradasi senyawa kitin dapat diketahui dari nilai indeks kitinolitiknya (IK). Chromobacterium sp. galur T51118 memiliki nilai IK lebih tinggi dibandingkan dengan Streptomyces sp. galur T51105.

\section{Agens Hayati sebagai Penginduksi Ketahanan Tanaman}

Analisis ekspresi tanaman menunjukkan bahwa enam agens hayati memiliki kemampuan sebagai penginduksi ketahanan tanaman dengan memicu tanaman meningkatkan kandungan total fenol, aktivitas kitinase, peroksidase, dan PAL (Tabel 3). Setiap agens hayati memiliki keunggulan yang berbeda sebagai penginduksi ketahanan tanaman.

\section{Karakter Agens Hayati dalam Mendukung Kebugaran Tanaman}

Indikator agens hayati mampu memproduksi siderofor ialah terbentuknya zona berwarna oranye di sekitar agens hayati, sementara yang menjadi indikator agens hayati mampu melarutkan fosfat ialah terbentuknya zona bening di sekitar agens hayati. Semua agens hayati mampu memproduksi siderofor, sementara hanya dua agens hayati yang mampu melarutkan fosfat, yaitu $R$. pickettii TT47 dan P. fluorescens P12 (Gambar 4).

\section{Kompatibilitas Antaragens Hayati}

Empat pasangan agens hayati yang kompatibel dalam uji kompatibilitas ini ialah $P$. fluorescens P12 dengan Chromobacterium sp. T51118, P. fluorescens $\mathrm{P} 12$ dengan $R$. pickettii TT47, Chromobacterium sp. T51118 dengan $R$. pickettii TT47, dan pasangan Bacillus subtilis EB4 451 dengan B. subtilis EA2 154 (Tabel 4).

\section{PEMBAHASAN}

Kajian sifat unggul suatu agens hayati terutama tentang mekanisme pengendalian menjadi tahap awal dalam pengembangan 
A

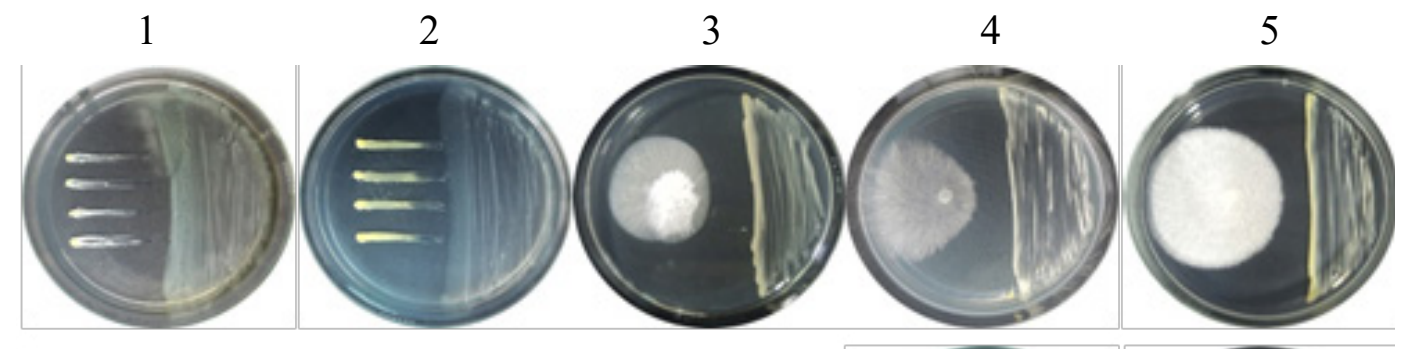

B

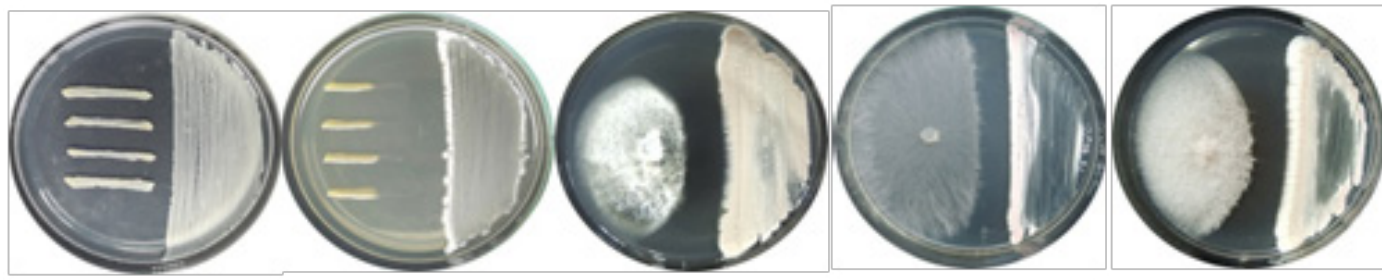

$\mathrm{C}$

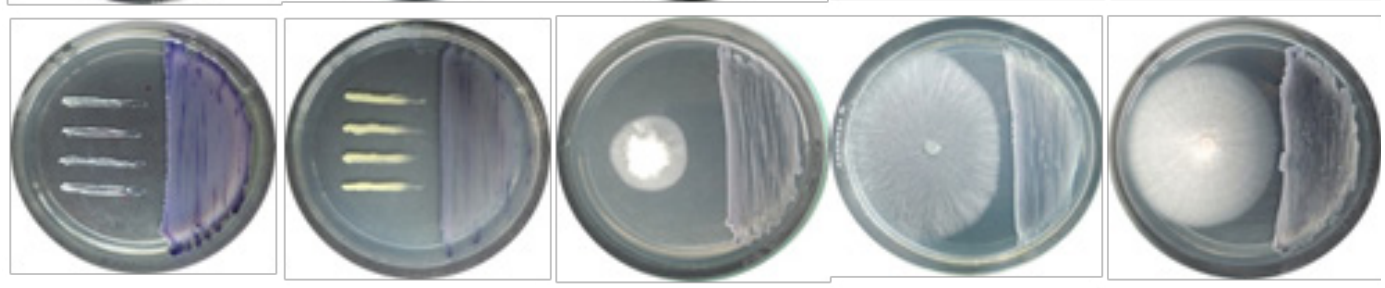

$\mathrm{D}$

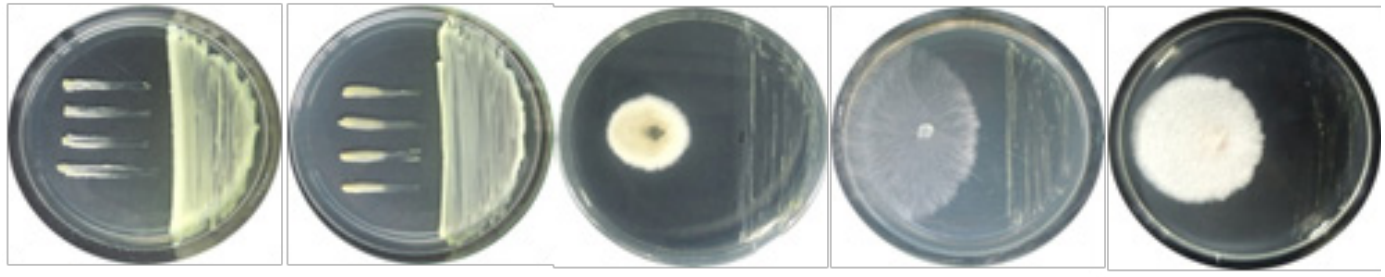

$\mathrm{E}$

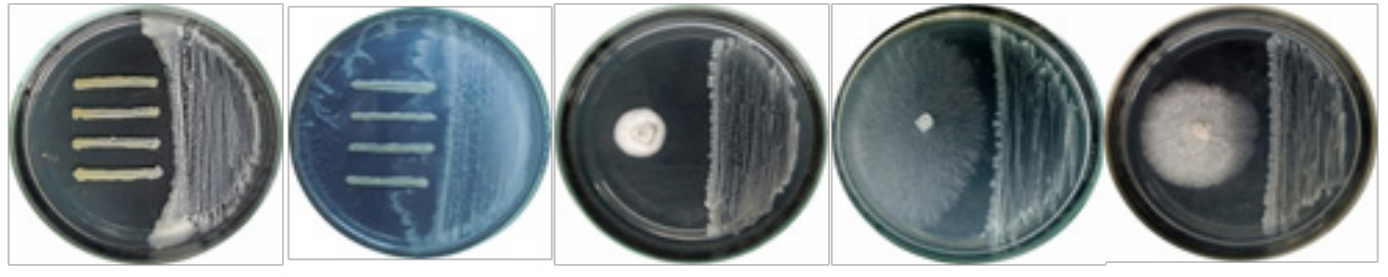

$\mathrm{F}$

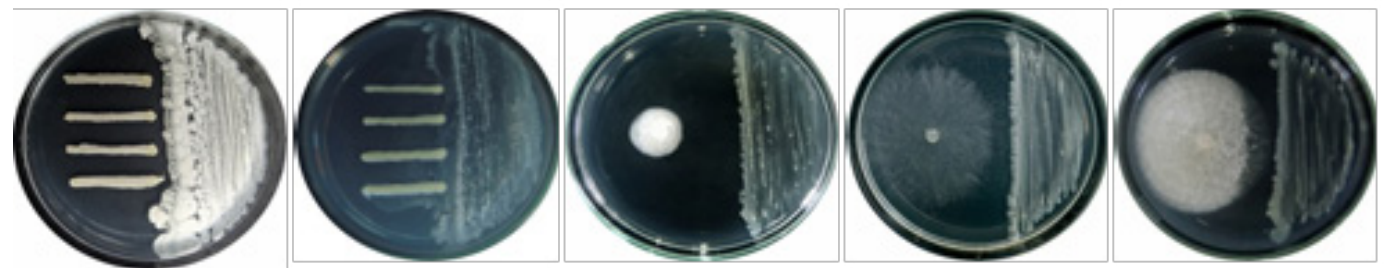

Gambar 1 Penghambatan pertumbuhan patogen oleh agens hayati dengan metode uji biakan ganda: A, Pseudomonas fluorescens P12; B, Streptomyces sp. T51105; C, Chromobacterium sp. T51118; D, Ralstonia pickettii TT47; E, Bacillus subtilis EA2 154; dan F, Bacillus subtilis EB4 451 terhadap patogen: 1, Burkholderia glumae; 2, Xanthomonas oryzae pv. oryzae; 3, Pyricularia oryzae; 4, Rhizoctonia solani; dan 5, Drechlera oryzae.

teknologi pengendalian hayati. Mekanisme pengendalian yang dimiliki agens hayati secara umum dibagi menjadi dua tipe, yaitu bersifat langsung dan tidak langsung. Mekanisme pengendalian secara langsung dapat berupa hiperparasit atau predasi, antibiosis atau lisis, sedangkan secara tidak langsung di antaranya kompetisi nutrisi, pertumbuhan tanaman, dan induksi ketahanan tanaman (Pal dan Gardener 2006).

Enam agens hayati yang diuji secara umum memiliki kedua tipe pengendalian, yaitu secara langsung dan tidak langsung. Mekanisme pengendalian secara langsung yang dimiliki 


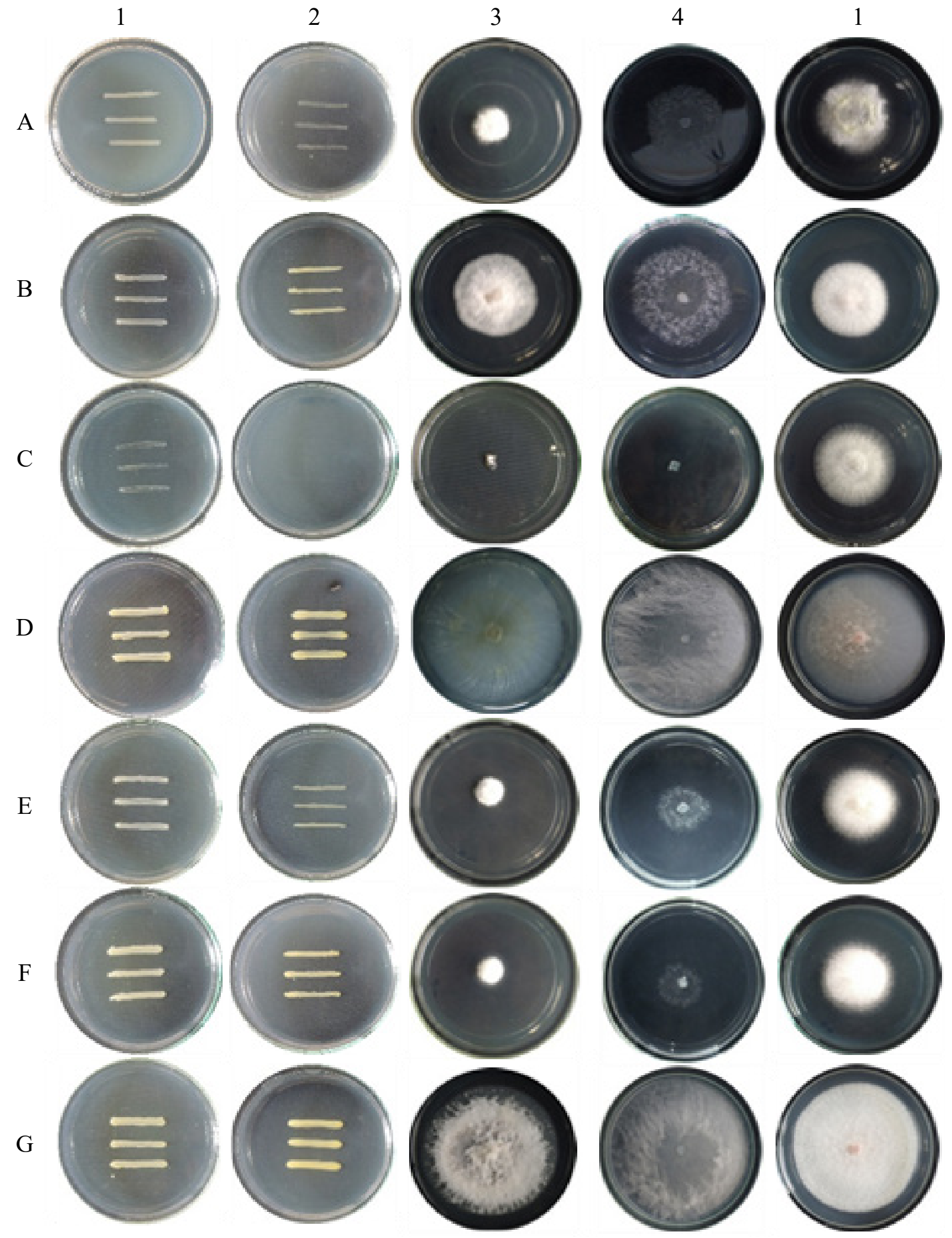

Gambar 2 Penghambatan pertumbuhan patogen oleh agens hayati dengan metode uji produksi senyawa volatil: A, Pseudomonas fluorescens P12; B, Ralstonia pickettii TT47; C, Chromobacterium sp. T51118; D, Streptomyces sp. T51105; E, Bacillus subtilis EA2 154; dan F, Bacillus subtilis EB4 451 terhadap patogen: 1, Burkholderia glumae; 2, Xanthomonas oryzae pv. oryzae; 3, Pyricularia oryzae; 4, Rhizoctonia solani; 5, Drechlera oryzae; dan G, Pertumbuhan patogen uji pada kontrol. 


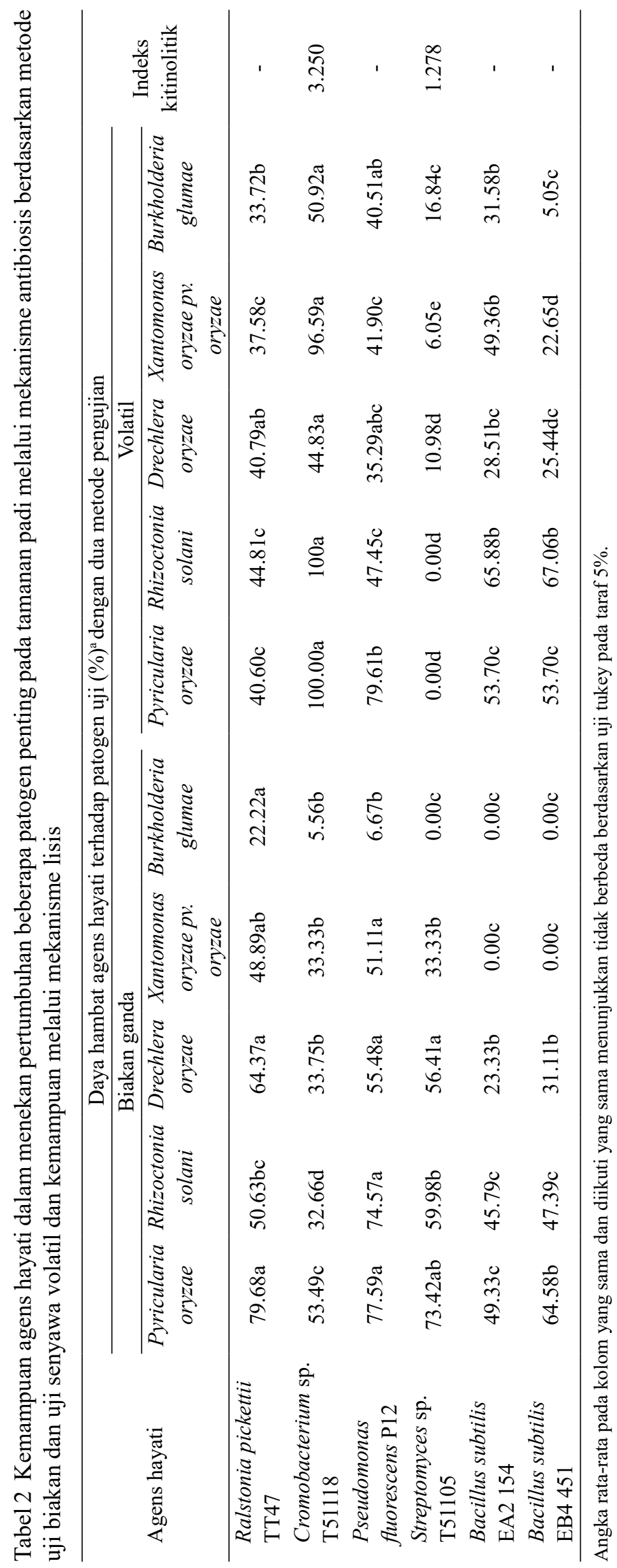


ialah antibiosis dengan menghasilkan senyawa antibiotik dan volatil, juga mekanisme lisis sel dengan menghasilkan enzim pendegradasi (lytic enzymes). Senyawa antibiotik dapat bersifat membunuh atau memberikan efek

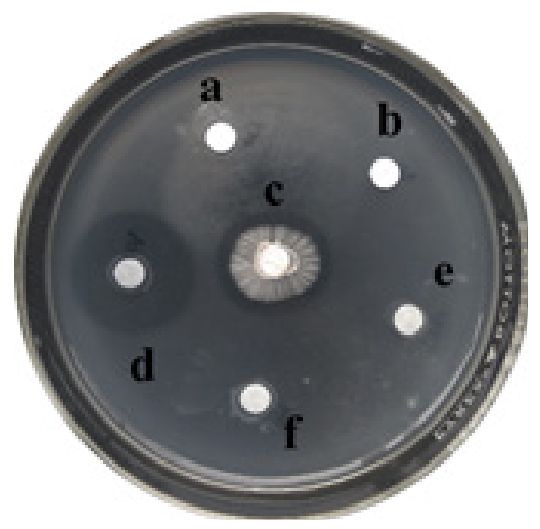

Gambar 3 Kemampuan agens hayati dalam produksi enzim kitinolitik. a, Bacillus subtilis EB4 451; b, Pseudomonas Fluorescens P12; c, Streptomyces sp. T51105; d) Chromobacterium sp. T51118, e) Ralstonia pickettii TT47, f) Bacillus subtilis EA2 154. penghambatan pertumbuhan mikrob dengan cara kerja di antaranya memengaruhi pembentukan dinding sel, menghambat sintetis protein, merusak fungsi membran plasma, menghambat sintetis DNA, dan menghambat pembentukan molekul esensial (Walker 2001; Leclere et al. 2005).

Mekanisme pengendalian secara tidak langsung dari agens hayati uji mampu menginduksi tanaman. Kemampuan agens hayati dalam menginduksi ketahanan tanaman merupakan pendekatan pengendalian dari dalam tanaman. Mekanismeinimemungkinkan tanaman membangun sistem pertahanan sendiri terhadap patogen sehingga akan lebih efisien dan bersifat berkelanjutan. Menurut Murthy et al. (2014) mekanisme ketahanan ini terbentuk dengan cara menginduksi tanaman untuk memperkuat sistem pertahanan melalui pembatasan perluasan infeksi patogen secara fisik, maupun dengan pengaktifan gen pengode kitinase, peroksidase (POX), PAL, atau polyphenol oksidase (PPO). Secara umum,

Tabel 3 Produksi total fenol, aktivitas kitinase, peroksidase, dan phenylalinin ammonia liase tanaman akibat adanya induksi agens hayati

\begin{tabular}{lcccc}
\hline \multirow{2}{*}{ Agens hayati } & \multicolumn{4}{c}{ Peningkatan (\%) } \\
\cline { 2 - 5 } & Total fenol & Aktivitas kitinase & Peroksidase & Aktivitas PAL \\
\hline Ralstonia pickettii TT47 & -2.98 & 74.75 & 66.66 & 91.57 \\
Chromobacterium sp. T51118 & 28.55 & -13.07 & 16.18 & 94.18 \\
Pseudomonas fluorescens P12 & 39.46 & 27.57 & 48.18 & 149.09 \\
Streptomyces sp. T51105 & -2.11 & -16.74 & 19.17 & 43.15 \\
Bacillus subtilis EA2 154 & -0.19 & 119.80 & 5.31 & 50.03 \\
Bacillus subtilis EB4 451 & 28.26 & 8.81 & 21.08 & 198.37 \\
\hline
\end{tabular}
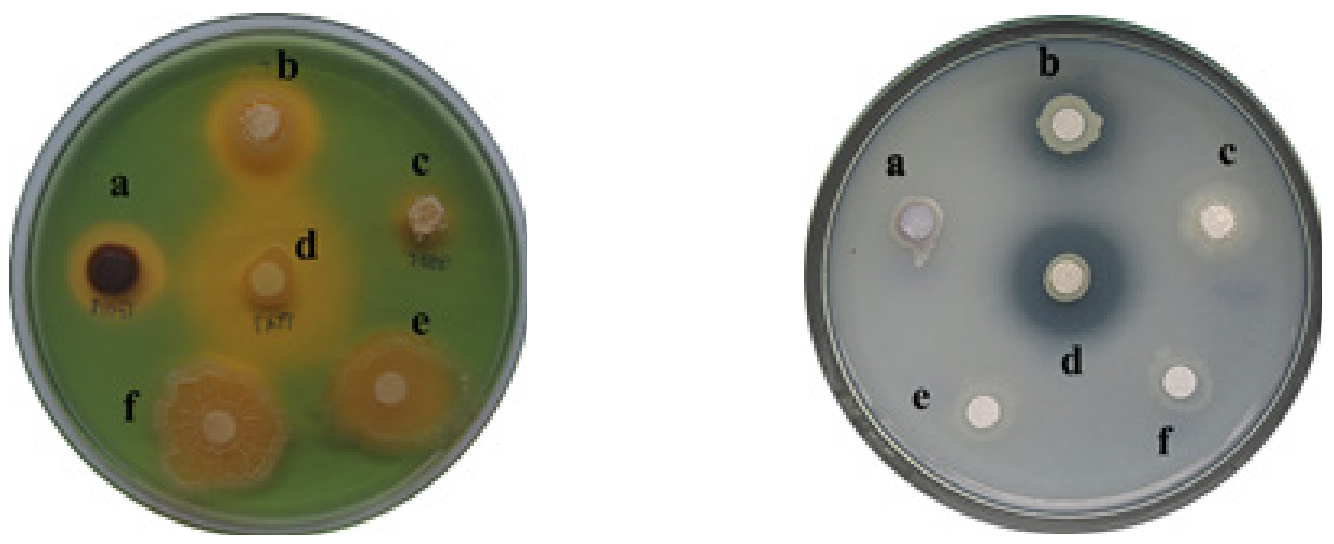

Gambar 4 Ekspresi agens hayati dalam memproduksi siderofor (kiri) dan fosfatase (kanan). a, Chromobacterium sp. T51118; b, Pseudomonas fluorescens P12; c, Streptomyces sp. T51105; d, Ralstonia pickettii TT47; e, Bacillus subtilis EA2 154; dan f, Bacillus subtilis EB4 451. 
J Fitopatol Indones

Dewi et al.

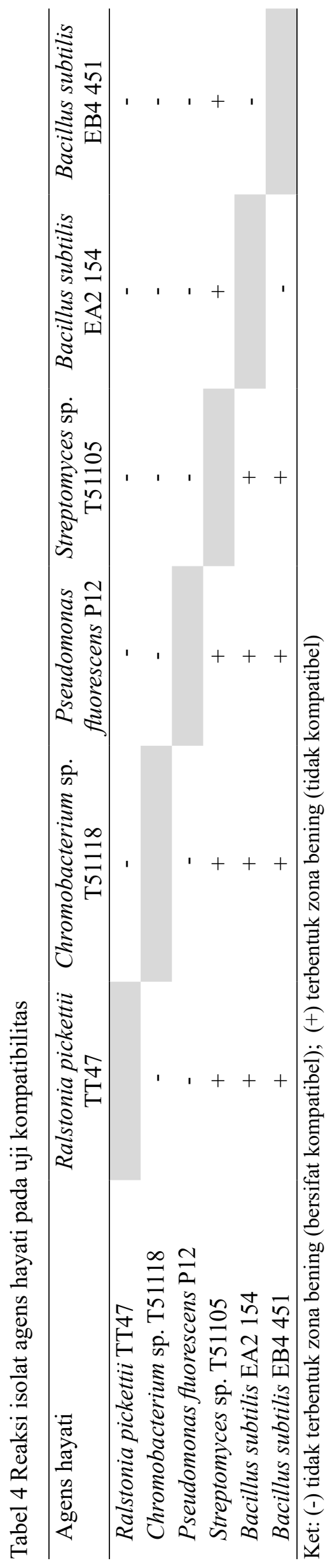


semua agens hayati mampu menginduksi ketahanan tanaman dengan meningkatkan total fenol tanaman, aktivitas kitinase, peroksidase, dan PAL.

Mekanisme tidak langsung lainnya ialah agens hayati uji berpotensi sebagai pendukung pertumbuhan tanaman dengan menghasilkan siderofor dan kemampuan melarutkan fosfat. Adanya karakter ini memungkinkan agens hayati mampu melindungi tanaman dari patogen melalui peningkatan kebugaran dan kesehatan tanaman sehingga terhindar dari serangan patogen.

Hasil pengujian terhadap enam agens hayati, diketahui bahwa $R$. pickettii TT47, P. fluorescens P12, B. subtilis EA2 154 dan EB4 451 memiliki mekanisme pengendalian melalui mekanisme antibiosis, mampu menginduksi ketahanan tanaman dan mendukung pertumbuhan tanaman dengan menghasilkan siderofor dan melarutkan fosfat. Sementara Chromobacterium sp. galur T51118 dan Streptomyces sp. galur T51105, selain memiliki ketiga karakter di atas, keduanya juga mampu menghasilkan enzim kitinase, artinya selain menekan patogen dengan senyawa antibiotik dan senyawa volatilnya, penekanan juga dapat dilakukan melalui penghancuran sel atau lisis. Enzim kitinase diketahui mampu menghidrolisis kitin yang merupakan komponen utama penyusun dinding sel cendawan. Kitinase menghidrolisis kitin dengan memutus ikatan $\beta-1,4$ homopolimer $\mathrm{N}$-asetilglukosamin menjadi monomer N-asetilglukosamin (Faramarzi et al. 2009).

Keunggulan lain dari enam agens hayati ini selain dari aspek mekanisme pengendaliannya ialah keberagaman patogen sasaran. Enam agens hayati tidak bersifat spesifik patogen sasaran, yaitu memiliki tiga hingga lebih patogen sasaran, bahkan $R$. pickettii TT47, P. fluorescens P12, dan Chromobacterium sp. T51118 memiliki kisaran patogen sasaran yang cukup luas. Ketiganya mampu menekan pertumbuhan $P$. oryzae, $R$. solani, D. oryzae, $X$. oryzae pv. oryzae, dan B. glumae.

Karakter unggul lainnya dari agens hayati yang diuji ialah kompatibel antaragens hayati.
Sifat kompatibel antaragens hayati akan lebih membantu dalam pencapaian target pengendalian, hal ini melihat mekanisme pengendalian yang dominan dari agens hayati tidak selalu sama.

Berdasarkan hasil penelitian ini diperoleh informasi bahwa enam agens hayati yang diuji memiliki sifat unggul dalam menekan patogen, yaitu memiliki mekanisme antibiosis dan lisis, mampu menginduksi ketahanan tanaman, dan mendukung kebugaran dan kesehatan tanaman. Selain itu agens hayati tersebut memiliki jenis patogen sasaran yang beragam. Hasil penelitian diperoleh tiga bakteri agens hayati yang unggul, yaitu $P$. fluorescens $\mathrm{P} 12$, R. pickettii TT47, dan Chromobacterium sp. galur T51118. Ketiganya mampu menekan pertumbuhan patogen mampu menginduksi ketahanan dan mendukung kebugaran tanaman, memiliki patogen sasaran yang lebih beragam, serta bersifat kompatibel.

\section{UCAPAN TERIMA KASIH}

Ucapan terima kasih disampaikan kepada Badan Penelitian dan Pengembangan Pertanian, Kementerian Pertanian yang telah membiayai Pendidikan program Doktor.

\section{DAFTAR PUSTAKA}

Alexander DB, Zuberer DA. 1991. Use of chrome azurol $\mathrm{S}$ reagents to evaluate siderophore production by rhizosphere bacteria. Biol Fertil Soils. 2:39-45. DOI: https://doi.org/10.1007/BF00369386.

Faramarzi MA, Fazeli M, Yazdi MT, Adrangi S, Al-Ahmadi KJ, Tasharrofi N, Mohseni FA. 2009. Optimization of cultural condition for production citinase by soil isolate of Massilia timonae. J Biotechnol. 8(1):93-99. DOI: https://doi.org/10.3923/ biotech.2009.93.99.

Haggag WM, Soud MAE. 2012. Production and optimization of Pseudomonas fluorescens biomass and metabolites for biocontrol of strawberry grey mould. Am J Plant Sci. 3:836-845. DOI: https://doi. org/10.4236/ajps.2012.37101. 
Kar M, Mishra D. 1976. Catalase, peroxidase, and polyphenoloxidase activities during rice leaf senescence. Plant Physiol. 57:315-319. DOI: https://doi.org/10.1104/ pp.57.2.315.

Karpagam T, Nagalakshmi PK. 2014. Isolation and characterization of phosphate solubilizing microbes from agricultural soil. Int J Curr Microbiol Appl Sci. 3(3):601-614.

Kartika R, Syafi'i W, Hanafi M. 2003. Aktivitas antijamur damar mata kucing. JTHH. 16(2):81-89.

Kurniawati S, Mutaqin KH. 2016. Eksplorasi dan uji senyawa bioaktif bakteri agensia hayati untuk pengendalian penyakit kresek pada padi. J HPT Tropika. 15(2):170 179. DOI: https://doi.org/10.23960/j. hptt.215170-179.

Leclere V, Bechet M, Adam A, Guez JS, Wathelet B, Ongena $M$, Thonart P, Gancel F, Chollet-Imbert M, Jacques P. 2005. Mycosubtilin overproduction by Bacillus subtilis BBG100 enhances the organism's antagonistic and biocontrol activities. Appl Environ Microbiol. 71:4577-4584. DOI: https://doi.org/10.1128/AEM.71.8.45774584.2005.

Mishra DS, Kumar A, Prajapati CR, Singh AK, Sharma SD. 2011. Identification of compatible bacteria and fungal isolate and their effectiveness against plant disease. $\mathrm{J}$ Environ Biol. 34:183-189.

Murthy KN, Uzma F, Chitrashree, Srinivas C. 2014. Induction of systemic resistance in tomato against Ralstonia solanacearum by Pseudomonas fluorescens. Am J Plant Sci. 5:1799-1811. DOI: https://doi. org/10.4236/ajps.2014.512193.

Ngadze E, Icishahayo D, Coutinho TA, van der Waals JE. 2012. Role of polyphenol oxidase, peroxidase, phenylalanine ammonia lyase, chlorogenic acid, and total soluble phenols in resistance of potatoes to soft rot. Plant Dis. 96:186-192. DOI: https://doi.org/10.1094/PDIS-02-11-0149.

Nurfadillah. 2016. Uji potensi dan kompatibilitas bakteri agens hayati untuk pengendalian Pyricularia oryzae penyebab penyakit blas pada padi [skripsi]. Bogor (ID): Institut Pertanian Bogor.

Pal KK, Gardener BM. 2006. Biological control of plant pathogens. Plant Health Inst. 2006: 1-25. DOI: https://doi. org/10.1094/PHI-A-2006-1117-02.

Parida I, Damayanti TA, Giyanto. 2016. Isolasi, seleksi, dan identifikasi bakteri endofit sebagai agens penginduksi ketahanan padi terhadap hawar daun bakteri. J Fitopatol Indones. 12(6):199-208.

Rustam.2012. Potensibakteripenghasil senyawa bioaktif anticendawan untuk pengendalian penyakit hawar pelepah padi [disertasi]. Bogor (ID): Institut Pertanian Bogor. Singh PP, Shin YC, Park CS, Chung YR. 1999. Biological control of fusarium wilt of cucumber by chitinolytic bacteria. Phytopathology. 89:92-99. DOI: https:// doi.org/10.1094/PHYTO.1999.89.1.92.

Sivan A, Ucko O, Chet I. 1987. Biological control of Fusarium crown rot of tomato by Trichoderma harzianum under field condition. Plant Dis 71:587-595. DOI: https://doi.org/10.1094/PD-71-0587.

Skidmore AM, Dickinson CH. 1976. Colony interaction and hyphal interference between Septoria nodorum and phylloplane fungi. Trans British Mycol Soc. 66(1):57-64. DOI: https://doi.org/10.1016/S00071536(76)80092-7.

Sukma D, Poerwanto R, Sudarsono R, Khumaida N, Artika IM, Wiyono S. 2012. Aktivitas kitinase dan peroksidase dari ekstrak kasar protein asal kalus dan berbagai jaringan tanaman Trichosanthes cucumerina var. anguina. J Agron Indones. 40(3):225-231.

Velho-Pereira S, Kamat NM. 2011. Antimicrobial screening of actiobacteria using a modified cross-streak method. Indian J Pharm Sci. 73(2): 223-228. DOI: https://doi.org/10.4103/0250-474X.91566.

Walker R, Innes CMJ, Allan EJ. 2001. The potential biocontrol agent Pseudomonas antimicrobial inhibits germination of conidia and outgrowth of Botrytis cinerea. Lett Appl Microbiol. 32:346348. DOI: https://doi.org/10.1046/j.1472765X.2001.00915.X. 